\title{
Four new species of Agrostis (Gramineae) from Australia
}

\author{
S.W.L. Jacobs
}

\begin{abstract}
Jacobs, S.W.L. (Royal Botanic Gardens, Sydney, NSW 2000, Australia) 2001. Four new species of Agrostis (Gramineae) from Australia. Telopea 9(3): 679-683. Four new species of Agrostis are described, A. bettyae and A. propinqua (both formerly included in A. hiemalis), A. thompsoniae and A. joyceae (both formerly included in A. parviflora). A key to the Agrostis species in New South Wales is provided.
\end{abstract}

\section{Introduction}

As part of the process of preparing a new edition of Grasses of New south Wales (Wheeler et al. 1990) it is necessary to provide names for three species of Agrostis that were included in Jacobs and Hastings (1993), and for a fourth taxon (A. joyceae), long kept separate in the NSW herbarium.

Agrostis bettyae and A. propinqua, have for many years in Australia been equated with the species A. hiemalis. Agrostis hiemalis is an American species and many of the Australian specimens labelled as such in US have a brief annotation, apparently in the hand of Agnes Chase, stating 'not true hiemalis'. The Australian species are native, and have never been thought of as introduced. Our material is not a good match for true A. hiemalis and, of the American species, is a closest match for A. scabra. Agrostis hiemalis has spikelets $1.5-1.7 \mathrm{~mm}$ long, lemma to $1.2 \mathrm{~mm}$ long, and anthers about $0.2 \mathrm{~mm}$ long. Agrostis scabra has spikelets 2-2.7 mm long, lemma 1.5-1.7 mm long, and anthers 0.4-0.5 mm long. Agrostis bettyae has spikelets 1.8-2 mm long, lemma 1.25-2 mm long, and the larger anthers $0.8-1 \mathrm{~mm}$ long. An examination of both Australian species at US indicated that our species also differ in:

(i) having the spikelets more clustered towards the end of the more flexuose branches;

(ii) often having short horizontal rhizomes;

(iii) the lower whorl of branches divided in the lower $50 \%$; and

(iv) dimorphic anther measurements, with cleistogamous spikelets having smaller anthers.

The description of these four new species brings to nine the number of species of Agrostis native to New South Wales, after the transfer of several taxa to Lachnagrostis (see Jacobs, this issue).

Agrostis bettyae S.W.L. Jacobs sp. nov.

A. scabrae similis sed spiculis versus extrematibus ramorum densius fasciculatis, verticillo inferno ramorum divisiore, antheris longioribus differt.

Holotype: AUSTRALIA: New South Wales: Southern Tablelands: Tallong [as ?Tallwong] W. Forsyth NSW506461, Jan 1900 (NSW; iso US). 
Erect or geniculately ascending, loosely tufted perennial to c. $90 \mathrm{~cm}$ tall, sometimes with a rather short horizontal rhizome; culms slender, c. 4-noded. Leaf sheath densely scaberulous to scabrous between the nerves; ligule jagged, 2-5 $\mathrm{mm}$ long; blade flat or becoming involute, grooved on the upper surface, acuminate, $1.5-4 \mathrm{~mm}$ wide. Inflorescence ovate to lanceolate in outline, narrow, lax, 10-35 cm long. Spikelets produced towards the ends of the ultimate branches, 2-2.5 $\mathrm{mm}$ long, often strongly purplish. Glumes subequal or the lower slightly longer, the length of the spikelet, sometimes hyaline towards the margins. Lemma truncate or minutely toothed, $1.25-2 \mathrm{~mm}$ long, unawned. Palea minute or absent. Anthers $0.8 \mathrm{~mm}$ or longer.

Habitat: montane woodland.

Distribution: along the Great Dividing Range from southern Queensland to central Victoria.

Named after my wife, Betty Jeanette Jacobs, in recognition of her long-suffering patience.

Notes: reported as Agrostis sp. A in Jacobs and Hastings (1993). Joyce Vickery at one stage considered naming this as a distinct species, A. neoanglica. Eventually she included it in her concept of $A$. hiemalis (Vickery 1941) though some specimens may have been distributed with her manuscript name. The species here presented includes a wider range of material, including much from outside the New England area, than covered by Vickery's brief notes and sorting, and her suggested epithet is not appropriate. Agrostis bettyae differs from A. scabra in having the spikelets more clustered towards the end of the branches, the lower whorl of branches being more divided and longer anthers.

Selection of specimens examined: Queensland: Wyberba, Blake 4605, Jan 1933 (NSW, BRI); Norris 481,482 \& Jacobs (NSW).

New South Wales: Northern Tablelands: Guyra, McKie, Mar 1938 (NSW); South Guyra, McKie 2324, Mar 1941 (NSW). Central Tablelands: Norway via Oberon, Vickery NSW506465, 26 Jan 1953 (NSW). Southern Tablelands: Wingello, Maiden NSW 506469, Mar 1900 (NSW). North Western Slopes: Inverell, Thomas 144/1913 (NSW). South Western Slopes: Holbrook, McBarron 504, Mar 1947 (NSW).

Victoria: Dandenong Range, Blake 7258 (NSW, BRI, MEL).

Agrostis joyceae S.W.L. Jacobs sp. nov.

A. parviflora similis sed inflorescentiae ampliori ramis flexuosioribus, pedicellis longioribus differt.

Holotype: AUSTRALIA: New South Wales: Southern Tablelands: Prussian Creek, alt. 5600' (1707 m) Kosciuszko [as Kosciusko] Nat. Park, in leaf litter on rock ledge, J. Thompson 2031, 1 Feb 1974 (NSW 506464).

Slender erect or ascending, loosely tufted annual to c. $40 \mathrm{~cm}$ tall; culms very slender, finely striate, c. 2-noded. Leaves crowded at the base; sheaths becoming loose from the culms in the upper part; ligule obtuse, to $3.5 \mathrm{~mm}$ long; blade mostly flat, to $1.5 \mathrm{~mm}$ wide. Inflorescence much exserted, open, pyramidal, slightly drooping or nodding, less than twice as long as wide, several-flowered, to $12 \mathrm{~cm}$ long, branches and pedicels flexuose; most pedicels of upper branches $>2 \mathrm{~mm}$ long, some to $5 \mathrm{~mm}$ long. Spikelets 1.8-2.5 mm long, pale greenish or sometimes purplish. Glumes acute, as long as the spikelet, sometimes hyaline towards the margins, subequal or the lower very slightly longer. Lemma truncate, $1.5-1.8 \mathrm{~mm}$ long, unawned. Palea minute. Anthers $0.4-0.5 \mathrm{~mm}$ long.

Habitat: comparatively dry areas near creeks in alpine areas. 
Distribution: Southern Tablelands of New South Wales.

The epithet is to acknowledge the large contribution made by Joyce W. Vickery to the study of Australian species of Agrostis and its relatives.

Notes: It is tempting to describe this taxon as a subspecies as it differs little from $A$ thompsoniae and A. parviflora in its measurements, but it grows sympatrically with both species and the specimens from mixed collections can be readily separated on the inflorescence characters. Agrostis joyceae differs from A. parviflora in the larger inflorescence with more flexuose branches and longer pedicels.

Specimens examined: New South Wales: Southern Tablelands: Prussian Creek, Thompson 2452 pp, Jan 1976 (NSW506471); Junction of Daners and Pipers Creek, Thompson 2808, Feb 1978 (NSW).

\section{Agrostis propinqua S.W.L. Jacobs sp. nov.}

A. scabrae similis sed spiculis versus extrematibus ramorum densius fasciculatis, verticillo inferno ramorum divisiore, spiculis brevioribus differt.

Holotype: AUSTRALIA: New South Wales: Southern Tablelands: Diggers Creek Valley, M. Mueller 1900, 1954, Snowy R. Hydro-Electric Authority, 'growing on dry mineral soil of road embankment.' (NSW 506463).

Erect or geniculate-ascending, loosely tufted perennials to c. $80 \mathrm{~cm}$ tall, sometimes with a rather short horizontal rhizome; culms slender, c. 4-noded. Leaf sheath densely scaberulous to scabrous between the nerves; ligule jagged, 2-5 $\mathrm{mm}$ long; blade flat or becoming involute, grooved on the upper surface, acuminate, $1.5-4 \mathrm{~mm}$ wide. Inflorescence ovate to lanceolate in outline, spreading, $10-35 \mathrm{~cm}$ long. Spikelets towards the ends of the ultimate branches, 1.8-2 $\mathrm{mm}$ long, often strongly purplish. Glumes subequal or the lower slightly longer, the length of the spikelet, sometimes hyaline towards the margins. Lemma truncate or minutely toothed, 1.25-2 mm long, unawned. Palea minute or absent. Anthers usually $<0.5 \mathrm{~mm}$ long.

Habitat: usually in damp or swampy areas.

Distribution: higher areas of the Southern Tablelands of New South Wales and adjoining areas of Victoria.

The epithet is derived from the Latin 'propinquus' meaning 'neighbouring', a reflection of Vickery's association of the taxon with $A$. hiemalis.

Notes: Known widely as A. hiemalis in Australia. Joyce Vickery at one time considered naming this as a distinct species, $A$. propinqua, but in the end included it in her concept of $A$. hiemalis (Vickery 1941); some specimens have been distributed with her manuscript name. Her concept of this species was broader than that used here, including some specimens I now include in A. bettyae above. Agrostis propinqua differs from A. scabra in having the spikelets more clustered towards the end of the branches, the lower whorl of branches being more divided and shorter spikelets.

Selection of specimens examined: New South Wales: Southern Tablelands: Cooma, Vickery NSW506473, Feb 1930 (NSW); Mt Kosciuszko [as Kosciusko], Vickery NSW506474, Jan 1930 (NSW); Geehi River, Vickery NSW506475, Jan 1959 (NSW).

Victoria: Splitters Range Study Block, Carr 10169, Dec 1984 (MEL, NSW, BRI); Mt Bogong, Black 27 (NSW). 
Agrostis thompsoniae S.W.L. Jacobs sp. nov.

A. parviflorae similis sed spiculis antherisque longioribus, foliis plerumque latioribus differt.

Holotype: AUSTRALIA: New South Wales: Southern Tablelands: Creek S.W. of Hedley Tarn, Kosciuszko [as Kosciusko] National Park. In gravel on wet creek flat with Luzula. J. Thompson 2889, 6 Feb 1978 (NSW506462).

Slender erect or ascending, loosely tufted annual to $40 \mathrm{~cm}$ tall; culms very slender, finely striate, c. 2-noded. Leaves crowded at the base; sheaths becoming loose from the culms in the upper part; ligule obtuse, to $5 \mathrm{~mm}$ long; blade mostly flat, to $2.5 \mathrm{~mm}$ wide. Inflorescence much exserted, more than twice as long as wide, few-flowered, to $12 \mathrm{~cm}$ long, branches and pedicels straight; most pedicels of upper branches $<2 \mathrm{~mm}$ long. Spikelets c. 1.5-2.5 mm long, pale greenish or sometimes purplish. Glumes acute, as long as the spikelet, sometimes hyaline towards the margins, subequal or the lower very slightly longer. Lemma truncate, 1.3-1.8 $\mathrm{mm}$ long, unawned. Palea minute. Anthers $0.4-0.5 \mathrm{~mm}$ long.

Habitat: in depressions, sod tussock grassland, and in fens, bogs and wet areas in alpine herbfields.

Distribution: alpine areas of New South Wales and Victoria.

Named after Joy Thompson, who drew my attention to this species, and also in recognition of her extensive contribution to our knowledge of the flora in alpine areas.

Notes: Reported as Agrostis sp. B in Jacobs and Hastings (1993). Agrostis thompsoniae differs from $A$. parviflora in having longer spikelets, longer anthers and usually wider leaves.

Selected specimens examined: New South Wales: Southern Tablelands: Ridge above Thredbo, Jacobs 4546 (NSW); Big Boggy near Dead Horse Gap, Thompson 2387 (NSW); Spencers Creek, Thompson 2564, 2570 (NSW); nr Snowy River, Totterdell 203, Mar 1971 (CANB, NSW).

Victoria: Nunniong Plateau, Beaglehole ACB36318 \& Finck, Jan 1971 (NSW, MEL); E slope of Cobberas, Wakefield 2943, Jan 1949 (NSW).

\section{Key to Agrostis species in New South Wales}

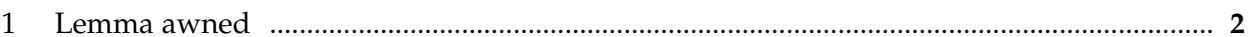

$1^{*}$ Lemma awnless ................................................................................................... 4

2 Awn minute and delicate (slender) arising from near the tip of the lemma and as long as the lemma; panicle contracted ........................................................................... A. muellerana

2* Awn one-and-a-half times to twice as long as the lemma and arising from about the middle

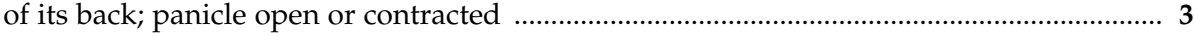

3 Spikelets 2-4 mm long; panicle open, with slender branches bare at the base for 2-6 cm A. venusta

3* Spikelets c. $2 \mathrm{~mm}$ long; panicle contracted, with erect branches divided or bearing spikelets to within $1 \mathrm{~cm}$ of their bases ............................................................................. A. boormanii

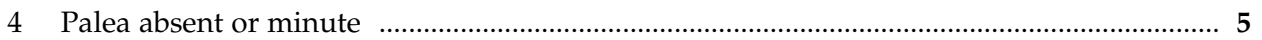

$4^{*} \quad$ Palea present, half to as long as the lemma ….............................................................. 11

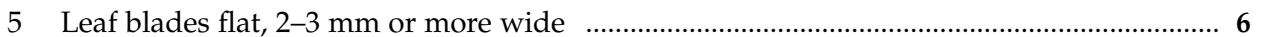

$5^{*}$ Leaf blades narrow, often folded, usually to $<2 \mathrm{~mm}$ wide when flat (leaf blades of A. bettyae may be to $2.5 \mathrm{~mm}$ wide) ………............................................................................... 7

6 Anthers < $0.5 \mathrm{~mm}$ long; spikelets $1.8-2 \mathrm{~mm}$ long …………............................ A. propinqua

$6^{*} \quad$ Anthers $1 \mathrm{~mm}$ long or longer; spikelets $1.8-2.2 \mathrm{~mm}$ long ........................................... bettyae 
7 Panicle contracted with erect branches; anthers $0.6-0.8 \mathrm{~mm}$ long

..A. muellerana

$7^{*}$ Panicle spreading, with branches often at right angles to the axis; anthers $0.3-0.5 \mathrm{~mm}$ long

Panicle usually only partly exserted from the upper leaves, glumes usually scabrous to the base of the keel; culms usually leafy

A. australiensis

8* Panicle much exserted on a long, smooth peduncle; glumes not scabrous to the base of the keel; leaves mostly crowded at the base of the culms

9 Anthers $0.3 \mathrm{~mm}$ long; leaves very fine, $<1 \mathrm{~mm}$ wide when folded

A. parviflora

9* Anthers $0.4-0.5 \mathrm{~mm}$ long; leaves to $2.5 \mathrm{~mm}$ wide when flat

10 Pedicels mostly $<2 \mathrm{~mm}$ long; inflorescence $>$ twice as long as wide, branches straight ........

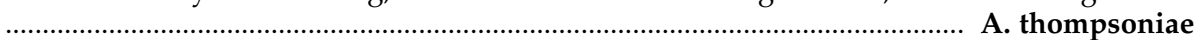

$10^{*}$ Pedicels $>2 \mathrm{~mm}$ long; inflorescence $<$ twice as long as wide, branches flexuose

A. joyceae

11 Spikelets falling with the glumes; panicle contracted

${ }^{*}$ A. viridis

$11^{*}$ Spikelets disarticulating between the glumes and the lemma; panicle more or less open, at least at anthesis

12 Ligule longer than broad; stoloniferous perennial; rhizomes, if present, with only 3 scale leaves; panicle branches often contracted after anthesis

*A. stolonifera

$12^{*}$ Ligule \pm longer than broad; rhizomatous (sometimes stoloniferous) and tufted perennials; rhizomes with at least 3 scale leaves; panicle branches not usually contracted after anthesis

13

13 Ligule shorter than wide, to $2 \mathrm{~mm}$ long; leaf blades to $5 \mathrm{~mm}$ wide; glumes only slightly scabrid on the keels

*A. capillaris

$13^{*}$ Ligule longer than wide, to $6 \mathrm{~mm}$ long; leaf blades broader, to $8 \mathrm{~mm}$ wide; glumes scabrid on the keels

A. gigantea

\section{Acknowledgments}

I thank Joy Thompson for her attempts at keeping me honest when dealing with small alpine grasses, Karen Wilson for the Latin descriptions, and Joy Everett for discussions on taxa delimitation.

\section{References}

Jacobs, S.W.L. and Hastings, S.M. (1993) Agrostis, pp. 569-574 in G.J. Harden (ed.), Flora of New South Wales, vol. 4. (New South Wales University Press: Sydney).

Vickery, J.W. (1941) A revision of the Australian species of Agrostis Linn. Contributions from the New South Wales National Herbarium 1, 101-119.

Wheeler, D.J., Jacobs, S.W.L. \& Norton, B.E. (1990) Grasses of New South Wales. 2nd edition. (University of New England Press: Armidale). 